\title{
Investigations by Ft-Ir Spectroscopy on Residues in Pottery Cosmetic Vases from Archaeological Sites in the Mediterra- nean Basin
}

\author{
Mariateresa Lettieri* and Maria Teresa Giannotta \\ Institute of Archaeological Heritage - Monuments and Sites, CNR-IBAM, Italy
}

\begin{abstract}
The present study was aimed at investigating, by FT-IR spectroscopy, residues in some whole archaeological vases, different in form and dimensions, but all classified as containers for cosmetics. The analyses performed on the as-sampled material and after extraction with a solvent were examined and compared. The results highlighted dissimilar composition of the residues for containers different in shape and provenance. Lipids, vegetable resins, and proteinaceous compound were identified. Also some inorganic products (such as calcite or clay minerals) were found as intended ingredients of the cosmetic preparations.

The FT-IR spectroscopy provided a simple, quick and cheap analytical method, which allows obtaining reliable and sound data using a limited preparation of the samples. In addition, this technique was found very useful in case of these unbroken precious artifacts, where damage has to be avoided.
\end{abstract}

\section{Keywords}

Fourier transform infrared spectroscopy, Residue analysis, Ancient cosmetics, Archaeological pottery

\section{Introduction}

In recent years, the identification of the residues in archaeological ceramic artifacts has caught the attention of different researches due to the interest of knowing better the daily life, commercial activities, and materials of ancient societies. To this aim, chromatographic techniques are frequently employed in identifying the organic residues [1-6]. However, these methodologies are destructive, while non-destructive or micro-destructive diagnostic techniques would be preferred, and procedures for sample preparation, usually taking a long time, are required. So, Fourier Transform Infrared (FT-IR) spectroscopy has been proposed for a rapid detection of organic residues in archaeological materials [7-12], as well as for investigations of the fabrication conditions [13-17].
As widely experienced in many applications [1823], this technique is very helpful because of its sensitivity, versatility and applicability to qualitative, but also semi-quantitative, analyses of both inorganic and organic compounds. The possibility of adapting the sampling methods and instrumental configurations makes it possible to analyse samples in different forms (solids, powders, particles, liquids or gases). In addition, accurate, reliable and reproducible analytical results are easily obtained, even where extremely reduced quantities of samples are available, thus facilitating the minimally invasive analysis of valuable artifacts.

Most of the studies applying FT-IR in the analysis of residues on archaeological potteries concern the detection of materials, usually in traces, which were in contact with vessels used for storing materials, as well as for pre-

*Corresponding author: Mariateresa Lettieri, Institute of Archaeological Heritage-Monuments and Sites, CNR-IBAM, Prov.le Lecce-Monteroni, 73100 Lecce, Italy, Tel: 39-0832-422219, Fax: +39-0832-422225, E-mail: mt.lettieri@ibam.cnr.it Received: April 07, 2017: Accepted: June 22, 2017: Published: June 24, 2017

Copyright: (@ 2017 Lettieri M, et al. This is an open-access article distributed under the terms of the Creative Commons Attribution License, which permits unrestricted use, distribution and reproduction in any medium, provided the original author and source are credited. 


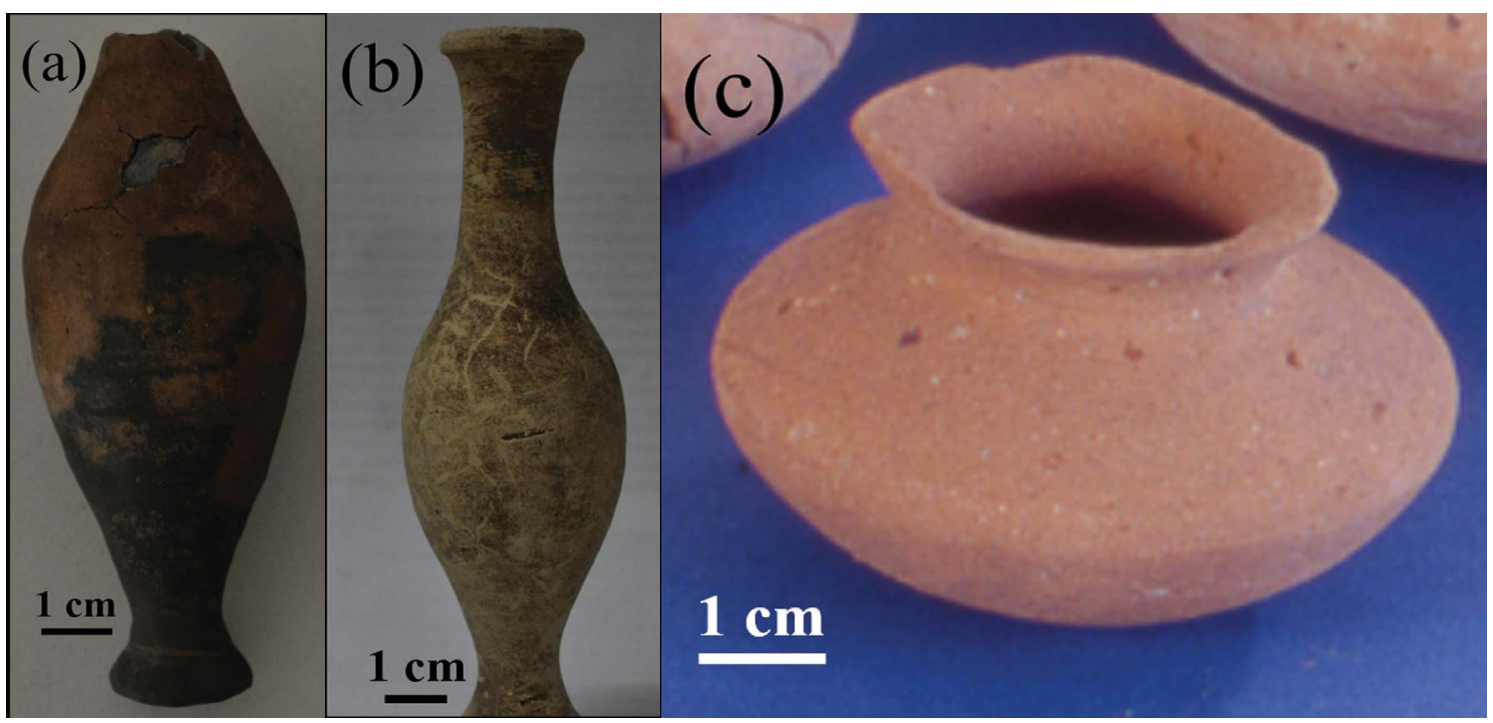

Figure 1: Photographs of the sampled vases: a) Unguentarium from the shipwreck in the site of Santa Sabina (Brindisi); b) Unguentarium from the hypogean tomb named Ipogeo delle Gorgoni (Taranto); c) Lenticular pixys from the sanctuary in Alaimo - Lentini (Sicily).

paring or cooking food [4,24-31]. In this field, perfumes, ointments, and cosmetics are investigated with growing interest, since some ingredients have been listed in ancient texts [32-36], but in most cases their preparation was a secret. These products were often a mixture of organic and inorganic compounds [37-40], therefore the FT-IR technique is a good choice to obtain information on both phases. In addition, a limited amount of material can be removed from the vessels, which are often precious and should be left intact or with minimal damage.

Starting from these issues, the present study was aimed at investigating residues in archaeological ceramic samples by means of FT-IR spectroscopy. This technique was chosen as a quick and cheap method to screen the samples before subjecting them to more expensive and time-consuming methodologies. Residues taken inside pottery vases, classified as containers for unguents and cosmetics, were analyzed. Both the organic and inorganic components were investigated to advance hypotheses about the function of the vases' content. The results highlighted dissimilar composition of the residues for containers different in shape and provenance.

\section{Materials and Methods}

\section{Archaeological samples}

The investigated samples were gathered in three ancient pottery vases discovered in different archaeological sites in the Mediterranean basin. The small vessels were unbroken and no residue was clearly visible inside, at least to the naked-eye.

Sample S1 was collected in an unguentarium (Figure $1 \mathrm{a})$, which was found in a shipwreck and referred as onboard equipment. The remains of the cargo ships were discovered at the site of Santa Sabina (Brindisi, South Italy) [41,42].

The vase is in grayish ceramic fabric and was dated to $2^{\text {nd }}$ century BC.

S2 was sampled in an unguentarium (Figure 1b) from a hypogean tomb in Taranto (South Italy), which is named Ipogeo delle Gorgoni $[43,44]$. Many unguentaria were found in the burial chamber. The selected vase is in pale orange ceramic fabric and was dated to the middle of the $2^{\text {nd }}$ century BC.

Finally, sample S3 was collected inside a lenticular pixys (Figure 1c) unearthed in a small square votive deposit near the sanctuary in Alaimo-Lentini (southeastern Sicily, Italy) [45,46]. This vessel, due to the shape and size, was characteristic of makeup containers produced in the western Greece. The ceramic fabric is orange and the piece was dated to the second half of the $7^{\text {th }}$ century BC. The use of this type of vessel is tied to ritual actions and offerings to the gods [47].

\section{Sampling and analytical procedures}

The internal surfaces of the vases were scraped with a scalpel to collect the material for the analysis.

A preliminary visual inspection of the samples was performed through a binocular stereomicroscope (Zeiss, mod. Stemi SV11) at magnifications of up to 100X. This examination was mainly aimed at trying to distinguish the residues of the content from the pottery material, inevitably taken away during the sampling.

The material gathered from the vessels was divided in two parts. The first one was finely ground with a pestle in an agate mortar, then mixed with $\mathrm{KBr}$ (suitable for 


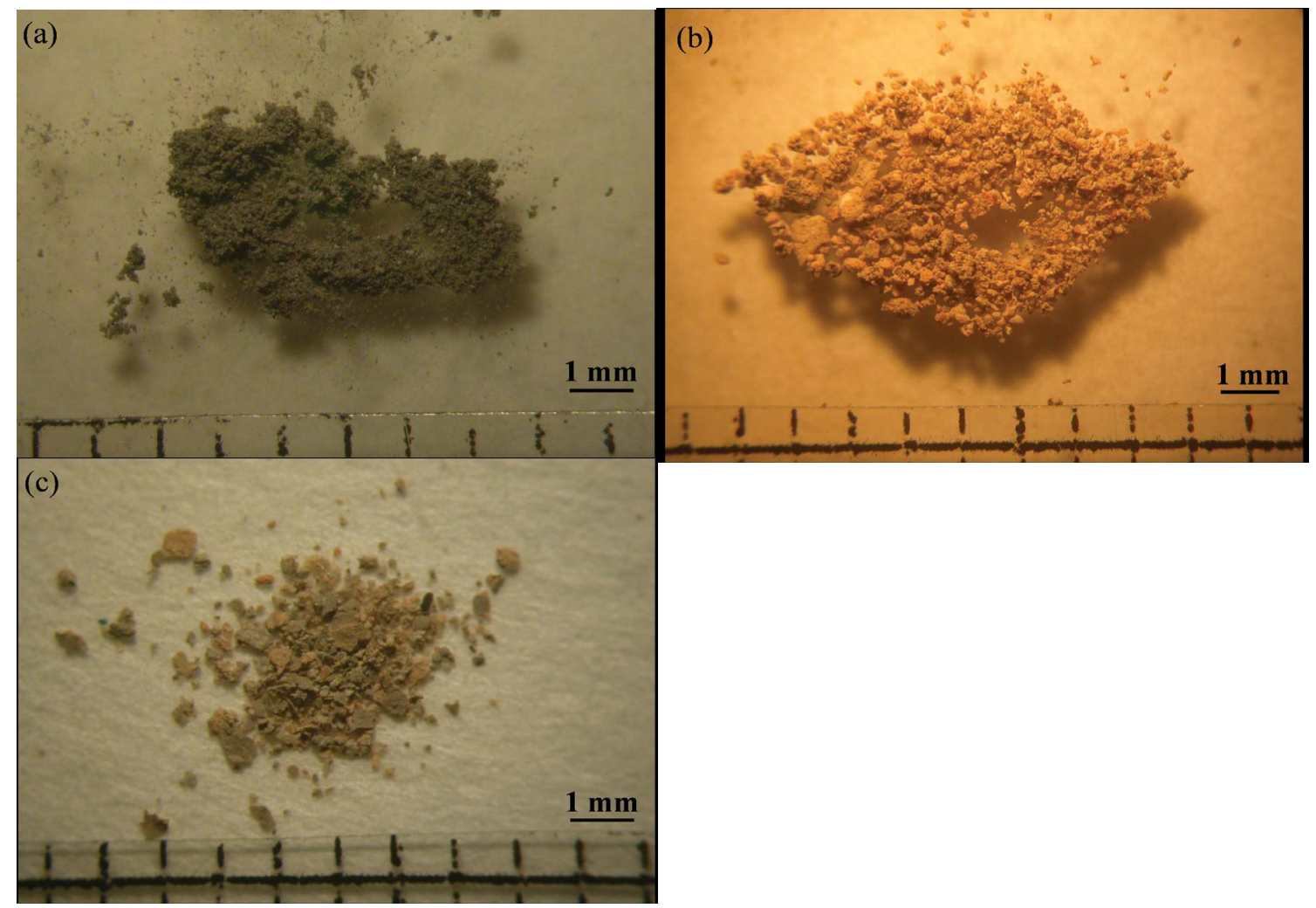

Figure 2: Images of the residues taken inside the vases: a) Sample S1; b) Sample S2; c) Sample S3.

Infrared analysis and provided by Mallinckrodt Baker Chemical Inc.) and compacted in a pellet $13 \mathrm{~mm}$ in diameter. A KBr die (Model 129, Thermo Spectra-Tech) and a hydraulic press (Mod 660, Silfradent) were employed to shape the pellets for the analyses. Following the manufacturer's suggestion, $6000 \mathrm{~kg}$ load was applied for approximately 1 minute. The second part of the collected material, placed in a vial, was extracted with acetone (analytical grade, provided by Carlo Erba Reagents), using 1 $\mathrm{ml}$ of solvent per $5 \mathrm{mg}$ of sample. Sonication was carried out for $22 \mathrm{~min}$ in an ultrasonic bath (FALC Instruments), followed by standing for 24 hours in laboratory conditions. The extraction with a solvent was adopted to identify the organic residues without interferences from both the environment deposits and the ceramic material. Acetone was used, as suggested in other studies $[4,25,48,49]$. A drop of the obtained liquid fraction was placed on a $\mathrm{KBr}$ pellet, previously prepared, which was stored for 5 minutes at $40{ }^{\circ} \mathrm{C}$ to enhance the solvent evaporation.

All the $\mathrm{KBr}$ pellets were analyzed in transmission mode, immediately after the preparation. A FT-IR Thermo Nicolet Nexus spectrometer, equipped with a Deuterated Triglycine Sulfate (DTGS) detector, was used. The spectra were acquired in the range of $4000-400 \mathrm{~cm}^{-1}$, with a resolution of $4 \mathrm{~cm}^{-1}$ and 200 scans per measurement; the background spectrum was collected on a pellet made of $\mathrm{KBr}$ only.

Where the analysis after the extraction was negative, $\mu$-ATR analyses were performed on the small flakes se- lected under the microscope, making it possible a selective examination of minimal portions of the sample. These spectra were acquired using a Thermo Nicolet Continuum IR microscope coupled with the spectrometer. This device was equipped with a Mercury-Cadmium-Telluride (MCT) detector, which was cooled with liquid Nitrogen. A $15 \times$ Reflachromat objective with a slide-on ATR attachment (Thermo Spectra-Tech), using a Si crystal (refractive index $=3.4$; incident angle $=45^{\circ}$; contact area $=50 \times 50 \mu \mathrm{m}$ ) was employed to collect the $\mu$-ATR spectra. To ensure reproducibility and uniformity, the contact between the ATR crystal and the sample surface was automated and computer controlled. After each analysis, the crystal was cleaned with a soft cloth soaked in acetone. The spectra were collected in the range of 4000-650 cm $\mathrm{cm}^{-1}$, with a resolution of $4 \mathrm{~cm}^{-1}$ and 200 scans for each measurement; the background spectrum was acquired in air.

The employed instrumentations were not purged with dry and $\mathrm{CO}_{2}$-free air, therefore the contribute of absorption bands of both $\mathrm{CO}_{2}$ (appearing in the spectrum as a doublet around $2340 \mathrm{~cm}^{-1}$ ) and water vapor (resulting in sharp and very close peaks over $3700 \mathrm{~cm}^{-1}$ ) are observed in the reported spectra, although a background spectrum was acquired before each analysis and automatically subtracted (by software) from the sample spectrum.

All the FT-IR data were processed with the OMNIC 8.1 software (Thermo Fisher Scientific Inc). 


\section{Discussion}

The preliminary observations through the stereomicroscope evidenced that the samples were different in appearance. The sample S1 consisted in a gray powder, homogeneous in color and texture (Figure 2a). Grains of whitish material came from S2; in this sample, tiny glossy elements were observed (Figure $2 b$ ). The samples S3 was mainly made of flakes either red or gray in color (Figure 2c). Actually, the most of these latter fragments consisted of both levels, suggesting that the grayish material was a coating on the reddish ceramic fabric (Figure $3 \mathrm{a}$ and Figure $3 b)$. Additionally, in this sample a very small green grain was found. A red-gray fragment and the green one were gathered to analyze them separately (Figure 3c).

The FT-IR peak wave numbers and assignments related to the compounds detected in the analyzed archaeo-
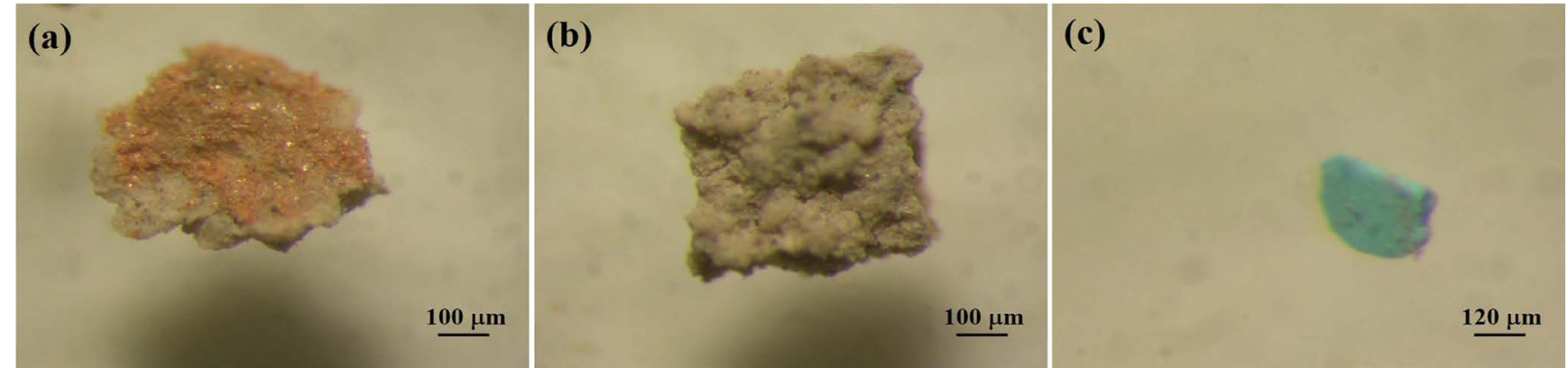

Figure 3: Images of flakes selected in the sample S3: a) and b) the two sides of a red-gray fragment; c) A green grain.

Table 1: Compounds detected in the analysed archaeological potteries, FT-IR peak wave numbers and assignments.

\begin{tabular}{|c|c|c|c|c|}
\hline \multirow{2}{*}{ Compound } & \multicolumn{2}{|c|}{ Peak wave numbers $\left(\mathrm{cm}^{-1}\right)$} & \multirow{2}{*}{ Vibrational assignment } & \multirow{2}{*}{ References } \\
\hline & In this study & literature & & \\
\hline \multirow{3}{*}{$\mathrm{CaCO}_{3}$} & $1420 ; 1423$ & $1435-1404$ & Asymmetric $\mathrm{CO}_{3}{ }^{2-}$ stretching of $\mathrm{CaCO}_{3}$ & {$[8,10,50,51]$} \\
\hline & 870; 873; 874; & $874-879$ & Asymmetric $\mathrm{CO}_{3}^{2-}$ bending of $\mathrm{CaCO}_{3}$ & {$[8,10,50,51]$} \\
\hline & $712 ; 716$ & $710-714$ & Symmetric deformation of $\mathrm{CO}_{3}{ }^{2-}$ of $\mathrm{CaCO}_{3}$ & {$[10,50,51]$} \\
\hline \multirow{5}{*}{ Silicates } & $1004 ; 1032 ; 1034 ; 1039$ & $1003-1041$ & Si-O stretching & {$[52,53]$} \\
\hline & $464 ; 467$ & $465-479$ & Si-O-Si deformation & [52] \\
\hline & $1634 ; 1644$ & $1630-1653$ & $\mathrm{OH}$ deformation of water & [52] \\
\hline & 3620 & $3619-3625$ & $\mathrm{OH}$ stretching of structural hydroxyl groups & {$[52,53]$} \\
\hline & 3690 & $3689-3696$ & $\mathrm{OH}$ stretching of structural hydroxyl groups of kaolinites & [52] \\
\hline \multirow{3}{*}{ Quartz } & 1080 & $1074-1086$ & Si-O stretching of quartz & {$[8,54]$} \\
\hline & $796 ; 799$ & 798-794 & Si-O stretching of quartz & {$[8,10]$} \\
\hline & $766 ; 773$ & $776-781$ & Si-O stretching of quartz & {$[8,10,55]$} \\
\hline Iron oxides & 520 & 577 & & [55] \\
\hline \multirow{3}{*}{ Kaolinites } & 1030 & $1036-1027$ & in-plane Si-O stretching & {$[52,53]$} \\
\hline & 1009 & $1011-1004$ & in-plane Si-O stretching & {$[52,53]$} \\
\hline & 912 & $912-915$ & $\mathrm{OH}$ deformation of inner hydroxyl groups & {$[52,53]$} \\
\hline \multirow{3}{*}{ Lipids } & $1726 ; 1728 ; 1734$ & $1751-1713$ & Ester $\mathrm{C}=\mathrm{O}$ stretching & [56-60] \\
\hline & 2926; 2927 & $2925-2928$ & Aliphatic $\mathrm{CH}_{2}$ asym. stretching & {$[10,61]$} \\
\hline & $2854 ; 2855$ & 2854-2856 & Aliphatic $\mathrm{CH}_{2}$ sym. stretching & {$[10,61]$} \\
\hline \multirow{4}{*}{ Oils } & 1743 & $1743-1747$ & Ester $\mathrm{C}=\mathrm{O}$ stretching & {$[10,61]$} \\
\hline & 1457 & $1461-1465$ & Asym. bending of aliphatic $\mathrm{CH}_{3}$ and $\mathrm{CH}_{2}$ groups & {$[10,25,49,61]$} \\
\hline & 1244 & $1236-1244$ & C-O stretching & [61] \\
\hline & 1162 & $1164-1170$ & C-O stretching & [61] \\
\hline \multirow{3}{*}{$\begin{array}{l}\text { Vegetable } \\
\text { resins }\end{array}$} & 2927 & $2922-2926$ & $-\mathrm{CH}_{2} /-\mathrm{CH}_{3}$ stretching & {$[8,25,48]$} \\
\hline & 2854 & $2848-2869$ & $-\mathrm{CH}_{2} /-\mathrm{CH}_{3}$ stretching & {$[8,25,48]$} \\
\hline & 1699 & $1694-1726$ & $\mathrm{C}=\mathrm{O}$ (stretching) in carboxylic acids/ester & {$[25,48]$} \\
\hline Pitch & 1716 & $1710-1730$ & ketone group as part of a ring structure & {$[7,8,62]$} \\
\hline \multirow{3}{*}{ Proteins } & 1650 & 1650 & $\mathrm{C}=\mathrm{O}$ (stretch) - Amide I band & {$[9,63,64]$} \\
\hline & 1543 & $1500-1565$ & $\begin{array}{l}\text { out-of-phase combination of the } \mathrm{NH} \text { in plane bending } \\
\text { and the } \mathrm{CN} \text { stretching vibration - Amide II band }\end{array}$ & {$[9,63,64]$} \\
\hline & 1458 & $1200-1450$ & $\begin{array}{l}\text { in-phase combination of the } \mathrm{NH} \text { bending and the } \mathrm{CN} \\
\text { stretching vibration - Amide III }\end{array}$ & {$[60,63]$} \\
\hline \multirow{2}{*}{$\begin{array}{l}\text { Absorbed } \\
\text { water (free) }\end{array}$} & $3420 ; 3428$ & $3420-3445$ & $\mathrm{H}-\mathrm{O}-\mathrm{H}$ stretching & {$[54,65]$} \\
\hline & $1630 ; 1640$ & $1620-1642$ & $\mathrm{H}-\mathrm{O}-\mathrm{H}$ bending & {$[54,55,65]$} \\
\hline
\end{tabular}


logical potteries were listed in Table 1. In the same Table, the bands observed in the present study were compared with those already published in the literature.

The FT-IR analyses performed in transmittance mode on sample S1 (Figure 4a) evidenced the presence of a great amount of calcium carbonate $(1420,874$, and $\left.716 \mathrm{~cm}^{-1}\right)$. Also silicates (1039 and $\left.464 \mathrm{~cm}^{-1}\right)$ and quartz $\left(1080,796\right.$, and $\left.766 \mathrm{~cm}^{-1}\right)$ were very abundant. The lack of signals above $3600 \mathrm{~cm}^{-1}$ suggested that the silicate compounds mainly came from the pottery. In fact, peaks around 3620 and $3690 \mathrm{~cm}^{-1}$ are indicative of raw materials from the environment and are usually not observed in fired archaeological ceramics, where the high firing temperatures cause the de hydroxylation of the clays [66-68]. The bands centered about $3428 \mathrm{~cm}^{-1}$ and $1630 \mathrm{~cm}^{-1}$ originated from the $\mathrm{OH}$ stretching and $\mathrm{H}-\mathrm{O}-\mathrm{H}$ bending of the absorbed water, respectively [55]. Water molecules can have been absorbed by the pottery $[65,69]$ during the long exposure in the underwater environment after the sinking of the ship.
A signal at $1726 \mathrm{~cm}^{-1}$ suggested the presence of organic compounds of lipidic nature.

The analysis performed after extraction with acetone was helpful to better identify the organic material in S1. The related result, reported in Figure 4b, matched a typical oil spectrum [60]. The $-\mathrm{CH}_{2}$ stretching peaks were very strong and were found at 2926 and $2855 \mathrm{~cm}^{-1}$. A strong and sharp carbonyl band of ester group was observed at $1743 \mathrm{~cm}^{-1}$. This is a "marker" band for identification of oils [60]. Other bands typical of oils were found at $1457 \mathrm{~cm}^{-1}$ (aliphatic C-H) and 1162 (C-O). Also in this spectrum, the signal at $3420 \mathrm{~cm}^{-1} \mathrm{can}$ be attributed to water molecules absorbed during the tests by both the sample and the $\mathrm{KBr}$ pellets.

These results are consistent with historical sources documenting that vegetable oils were predominantly utilized as the lipid base for scented unguents and perfumes [70-72]. Among them, non-drying oils (e.g. almond oil, olive oil) were found to be more suitable to obtain substances with the proper texture for an easy application
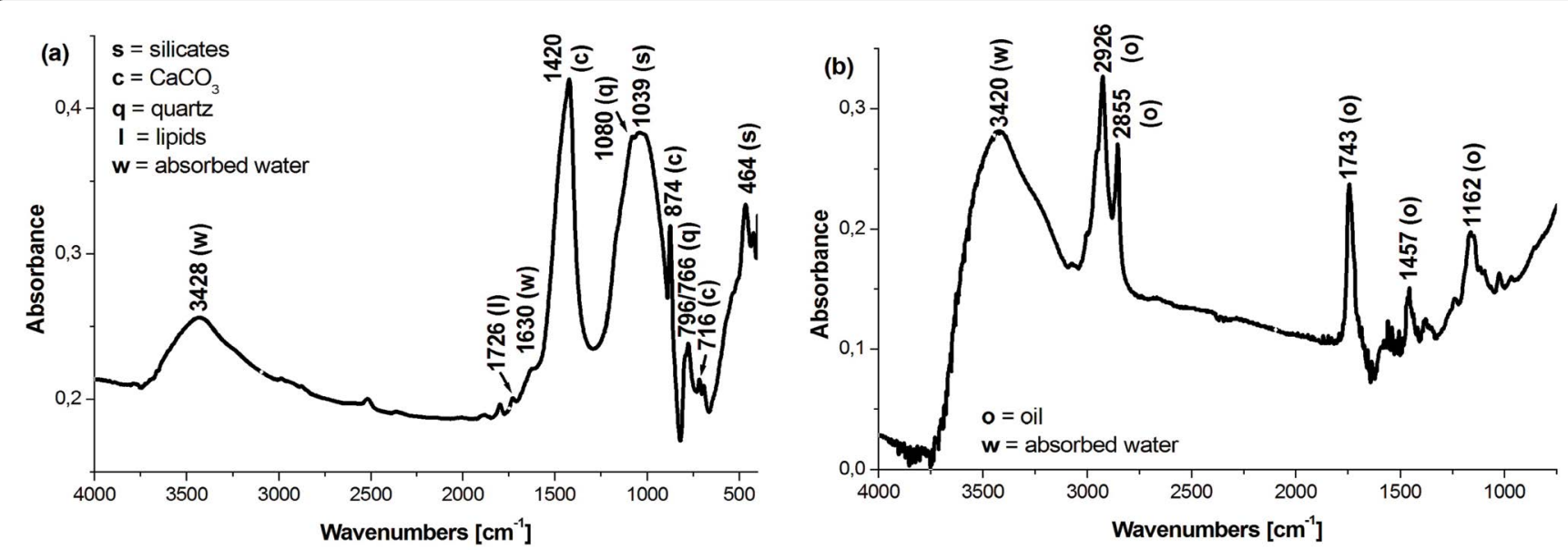

Figure 4: Spectra collected in transmission mode on the $\mathbf{S 1}$ sample: a) As-sampled powder; b) Liquid obtained by extraction with acetone.
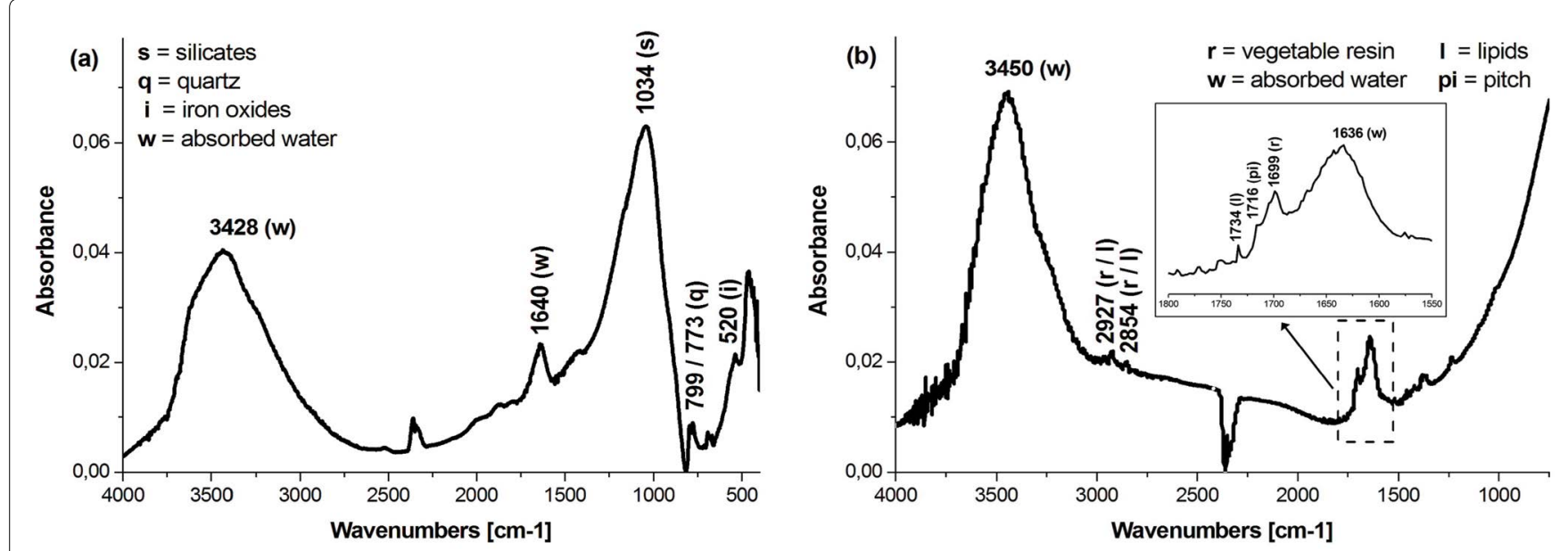

Figure 5: Spectra collected in transmission mode on the $\mathbf{S 2}$ sample: a) As-sampled powder; b) Liquid obtained by extraction with acetone (the range between 1500 and $1800 \mathrm{~cm}^{-1}$ has been expanded in the inset box). 
on the skin [30]. It is to take into account that, since in ancient times olive production was widely spread in the Mediterranean Basin, olive oil became the most common excipient in the preparation of perfumes and cosmetics. In addition, inorganic compounds were added to the unguents $[73,74]$, therefore the high content of calcium carbonate found in S1 could arise from an intended ingredient.

In the spectrum of sample S2, acquired in transmission mode (Figure 5a), the strong absorption band at $1034 \mathrm{~cm}^{-1}$ allowed to recognize silicate minerals as the main constituents. The characteristic doublet at 799 and $773 \mathrm{~cm}^{-1}$ and the signal around $520 \mathrm{~cm}^{-1}$, accounted for the presence of quartz and iron oxide minerals, respectively. The bands at 3428 and $1640 \mathrm{~cm}^{-1}$, due to water, very probably originated from hydration of minerals in the ceramic body as a consequence of the exposure to water/humidity in the burial environment. Finally, no organic substance was identified.

The result of FT-IR analysis on the liquid obtained by extraction with acetone is reported in Figure 5b. In this spectrum, the strongest bands, found at 3450 and 1636 $\mathrm{cm}^{-1}$, can be due to water molecules soaked up during the tests or absorbed in the clay structure $[10,12,75]$. The weak absorption observed at $1734 \mathrm{~cm}^{-1}$ suggested the presence of lipids in traces. The peaks around 2927 and $2854 \mathrm{~cm}^{-1}$, due to stretching vibrations of $-\mathrm{CH}_{2}$, can be ascribed to both lipids and vegetable resins $[11,60,76]$. The resins also gave rise to signals at 1699 and $1716 \mathrm{~cm}^{-1}$ as the stretching bands of carbonilic groups. In particular, the signal at $1716 \mathrm{~cm}^{-1}$ was indicative of ketone groups typically found in pitch $[7,8,25]$.

According to classical sources, resins are among the main ingredients of ancient ointments and medical remedies $[77,78]$. Due to their antifungal, antibacterial, and aromatic properties, these products were also applied as embalming products $[79,80]$. Actually, the finding of this pottery in a tomb could relate its use to funerary practices. In addition, the low amounts of organic compounds inside the vessel could suggest that the vase was empty for a long time and likely the content was used just before the burial.

The as-sampled S3 powder, analyzed in transmittance mode (Figure 6), mainly contained silicates (1032, 467 , and $\left.1634 \mathrm{~cm}^{-1}\right)$ and calcium carbonate $(1423,873$, and $\left.712 \mathrm{~cm}^{-1}\right)$. No evidence of organic compounds was found. Also the analysis of the liquid extract from this sample was negative. Therefore, the small fragments (Figure 3) selected under the stereomicroscope (see section "Sampling and analytical procedures") were separately analyzed in $\mu$-ATR mode.

The red-gray fragment was examined on both the surfaces. The two spectra (Figure 7) were quite similar,

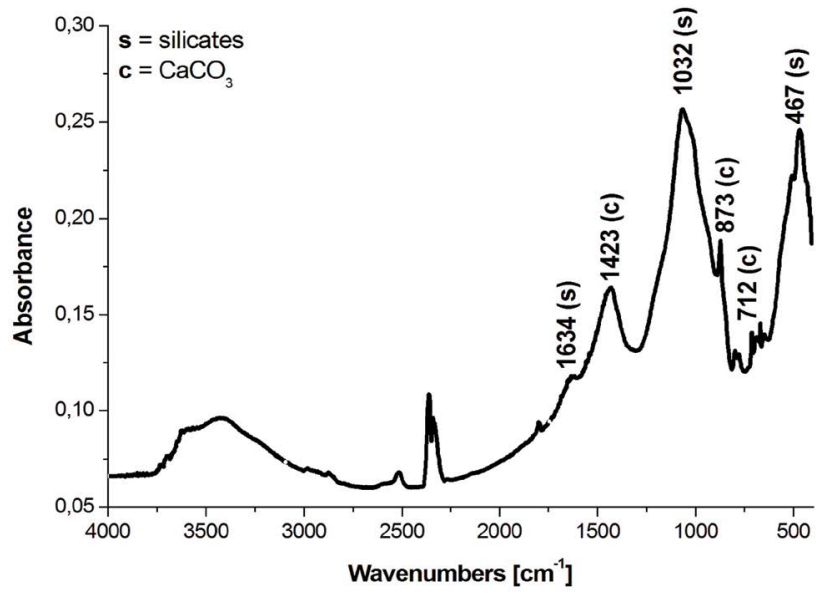

Figure 6: Spectrum collected in transmission mode on the S3 sample.

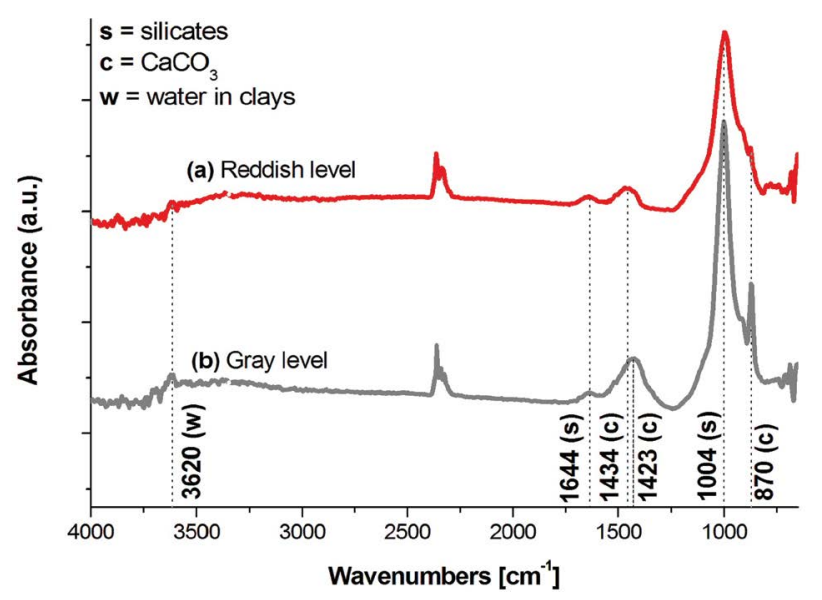

Figure 7: $\mu$-ATR spectra collected on the two-level fragment from S3: a) The reddish level (see Figure 3a); b) The gray level (see Figure 3b).

showing the silicates (1004 and $1644 \mathrm{~cm}^{-1}$ ) as the main components and a certain amount of calcium carbonate $\left(1423\right.$ and $\left.870 \mathrm{~cm}^{-1}\right)$. This latter was more abundant on the gray side, suggesting that this level originated from soil residues. In fact, in the same level, a peak was detected at $3620 \mathrm{~cm}^{-1}$, which can be attributed to unfired clay minerals. In both cases, no signals ascribable to organic materials were found.

On the contrary, interesting results were obtained from the FT-IR analysis carried out in $\mu$-ATR mode on the green fragment (Figure 8). In this spectrum, peaks at 1728 and $1244 \mathrm{~cm}^{-1}$ can be ascribed to a lipid. In addition, bands at 1650,1543 , and $1458 \mathrm{~cm}^{-1}$ were recognized. These three signals are referred to as amide I, amide II, and amide III, respectively, and form the typical pattern of proteinaceous materials [60]. This was an unexpected result since proteins easily suffer denaturation and have been rarely detected in archeological pottery. However, in the literature some studies discuss about 


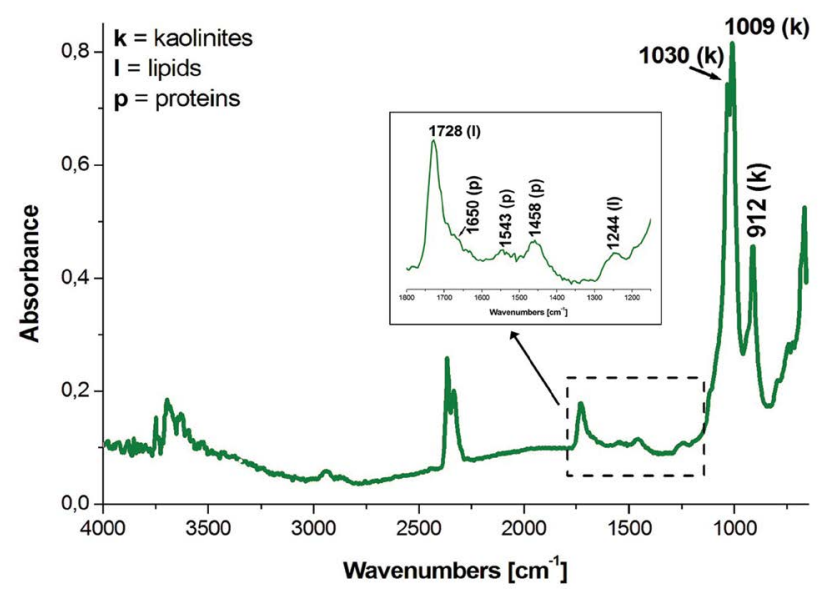

Figure 8: $\mu$-ATR spectrum collected on the green grain from S3 (see Figure 3c); the range between 1150 and $1800 \mathrm{~cm}^{-1}$ has been expanded in the inset box.

proteinaceous compounds which survive to decay because of protective coatings [81], as collagen from boiled meat [82], or in stick for make-up purposes [83]. In the spectrum of the green fragment, the strongest peaks were found at 1030, 1009 e $912 \mathrm{~cm}^{-1}$, which are due to inorganic clay minerals belonging to the kaolinite group [84]. From the ancient times until nowadays, these kind of materials have been frequently used in cosmetics, as well as in pharmaceutical applications $[85,86]$. The clay mineral probably protected the proteinaceous material against the degradation processes. The absence organic compounds in the whole sample suggested that the pyxis did not contain liquid substances. The obtained results let us suppose that the green fragment was the residue of a solid material used as a cosmetic make-up.

\section{Conclusions}

In this study some whole pottery vases, different in form and dimensions, but all classified as containers for cosmetics, were analyzed by FT-IR spectroscopy. The results obtained from investigations on the as-sampled material and after extraction with a solvent were examined and compared.

The knowledge achieved about the sampled artifacts and their contents depended on the analyzed sample, on its collection and preparation, as well as on the applied test methodology. The analyses in transmission mode on samples scraped as a powder provided information mainly about inorganic materials. In particular, the constituent materials of the pottery and the residues from the soil and/or the environment were easily detected. The presence of inorganic materials limited the detection of organic compounds, usually found in traces. However, the extraction with a solvent helped to identify the organic substances, even if just a partial characterization was performed, due to the intrinsic limits of the FT-IR technique. The analyses in $\mu$-ATR mode allowed a selective and useful examination of minimal portions of the sample.

The use of the sampled artifacts as cosmetic vases was confirmed. The obtained data allowed tracing a rough composition of the content, which, in accordance with the ancient texts, resulted essentially based on organic materials (lipids, vegetable resins, and proteinaceous compounds). Also inorganic compounds were found as intended ingredients of the preparation, probably added as pigments or to tune the texture of the cosmetic.

The detection of the organic compounds together with the ceramic material let suppose the storage, inside the containers, of a liquid substance (to some extent viscous) which penetrated into the porous fabric of the pottery. In this case, a selective sampling of the residues was not possible. In fact, where the organic compounds and the pottery were not identified in the same sample, well distinguishable residues due to the content were observed, suggesting the presence of a cosmetic in solid form.

The obtained results confirmed that the FT-IR spectroscopy provides a simple, fast and economical analytical method, which allows obtaining reliable and sound data using a limited or no preparation of the samples. In addition, this technique was found very useful in case of unbroken artifacts, when the archaeological objects cannot be moved into the laboratory, and where an extensive sampling - and the damage thereof - has to be avoided.

\section{Acknowledgements}

Thanks go to Prof. Rita Auriemma (Università del Salento - Dipartimento Beni Culturali) for providing the unguentarium from the shipwreck in Santa Sabina. The authors are grateful to Soprintendenza Archeologica di Taranto for the opportunity to analyze the artifacts from the Ipogeo delle Gorgoni and for providing the archaeological samples. Thanks are also due to Soprintendenza per i Beni Culturali e Ambientali di Siracusa for granting access to the Museo Archeologico di Lentini in order to perform the sampling.

\section{References}

1. RP Evershed (2008) Organic residue analysis in archaeology: the archaeological biomarker revolution. Archaeometry 50: 895-924.

2. M Regert (2011) Analytical strategies for discriminating archeological fatty substances from animal origin. Mass Spectrom Rev 30: 177-220.

3. S Mitakidou, E Dimitrakoudi, D Urem Kotsou, D Papadopoulou, K Kotsakis, et al. (2008) Organic residue analysis of Neolithic pottery from North Greece. Microchim Acta 160: 493.

4. MP Colombini, G Giachi, F Modugno, E Ribechini (2005) Characterisation of organic residues in pottery vessels of 
the Roman age from Antinoe (Egypt). Microchem J 79: 8390.

5. D Arobba, F Bulgarelli, F Camin, R Caramiello, R Larcher, et al. (2014) Palaeobotanical, chemical and physical investigation of the content of an ancient wine amphora from the northern Tyrrhenian sea in Italy. J Archaeol Sci 45: 226233.

6. K Romanus, J Baeten, J Poblome, S Accardo, P Degryse, et al. (2009) Wine and olive oil permeation in pitched and non-pitched ceramics: relation with results from archaeological amphorae from Sagalassos, Turkey. J Archaeol Sci 36: 900-909.

7. J Font, N Salvadó, S Butí, J Enrich (2007) Fourier transform infrared spectroscopy as a suitable technique in the study of the materials used in waterproofing of archaeological amphorae. Anal Chim Acta 598: 119-127.

8. LM Shillito, MJ Almond, K Wicks, LJ Marshall, W Matthews (2009) The use of FT-IR as a screening technique for organic residue analysis of archaeological samples. Spectrochim Acta A Mol Biomol Spectrosc 72: 120-125.

9. TFM Oudemans, JJ Boon, RE Botto (2007) FTIR and solid-state ${ }^{13} \mathrm{C}$ CP/MAS NMR spectroscopy of charred and non-charred solid organic residues preserved in roman iron age vessels from the Netherlands. Archaeometry 49: 571594.

10. G Tarquini, S Nunziante Cesaro, L Campanella (2014) Identification of oil residues in Roman amphorae (Monte Testaccio, Rome): A comparative FTIR spectroscopic study of archeological and artificially aged samples. Talanta 118: $195-200$.

11. F Mizzoni, S Nunziante Cesaro (2006) Study of the organic residue from a 2600-year old Etruscan plumpekanne. Spectrochim Acta A Mol Biomol Spectrosc 68: 377-381.

12. M Lettieri (2015) Infrared spectroscopic characterization of residues on archaeological pottery through different spectra acquisition modes. Vibrational Spectroscopy 76: 48-54.

13. R Ravisankar, S Kiruba, C Shamira, A Naseerutheen, PD Balaji, et al. (2011) Spectroscopic techniques applied to the characterization of recently excavated ancient potteries from Thiruverkadu Tamilnadu, India. Microchem J 99: 370375.

14. G Velraj, R Ramya, R Hemamalini (2012) FT-IR spectroscopy, scanning electron microscopy and porosity measurements to determine the firing temperature of ancient megalithic period potteries excavated at Adichanallur in Tamilnadu, South India. J Mol Struct 1028: 16-21.

15. MJ Ayora Cañada, A Domínguez Arranz, A Dominguez Vidal (2012) Raman Microspectroscopic study of Iberian pottery from the La Vispesa archaeological site, Spain. J Raman Spectrosc 43: 317-322.

16. SA Centeno, VI Williams, NC Little, RJ Speakman (2012) Characterization of surface decorations in Prehispanic archaeological ceramics by Raman spectroscopy, FTIR, XRD and XRF. Vib Spectrosc 58: 119-124.

17. GA Mazzocchin, F Agnoli, I Colpo (2003) Investigation of roman age pigments found on pottery fragments. Anal Chim Acta 478: 147-161.

18. BH Stuart (2004) Infrared Spectroscopy: Fundamentals and Applications, John Wiley \& Sons, Ltd, Chichester (UK).
19. LE Rodriguez Saona, ME Allendorf (2011) Use of FTIR for Rapid Authentication and Detection of Adulteration of Food. Annual Review of Food Science and Technology 2: 467483.

20. Y Chen, C Zou, M Mastalerz, S Hu, C Gasaway, et al. (2015) Applications of Micro-Fourier Transform Infrared Spectroscopy (FTIR) in the Geological Sciences - A Review. Int J Mol Sci 16: 30223-30250.

21. Z Movasaghi, S Rehman, I ur Rehman (2008) Fourier Transform Infrared (FTIR) Spectroscopy of Biological Tissues. Applied Spectroscopy Reviews 43: 134-179.

22. F Zaera (2014) New advances in the use of infrared absorption spectroscopy for the characterization of heterogeneous catalytic reactions. Chem Soc Rev 43: 7624-7663.

23. AV Ewing, SG Kazarian (2017) Infrared spectroscopy and spectroscopic imaging in forensic science. Analyst 142: 257-272.

24. F Dorrego, F Carrera, MP Luxán (2004) Investigations on Roman amphorae sealing systems. Materials and Structures 37: 369-374.

25. FC Izzo, E Zendri, A Bernardi, E Balliana, M Sgobbi (2013) The study of pitch via gas chromatography-mass spectrometry and Fourier-transformed infrared spectroscopy: the case of the Roman amphoras from Monte Poro, Calabria (Italy). Journal of Archaeological Science 40: 595-600.

26. E Ribechini, F Modugno, C Baraldi, P Baraldi, MP Colombini (2008) An integrated analytical approach for characterizing an organic residue from an archaeological glass bottle recovered in Pompeii (Naples, Italy). Talanta 74: 555-561.

27. S Zareva, I Kuleff (2010) The application of the derivative IR-spectroscopy and HPLC-ESI-MS/MS in the analysis of archaeology resin. Spectrochimica Acta A 76: 283-286.

28. PE McGovern, DL Glusker, LJ Exner, MM Voigt (1996) Neolithic resinated wine. Nature 381: 480-481.

29. C Cardell, I Guerra, J Romero Pastor, G Cultrone, A Rodriguez Navarro (2009) Innovative Analytical Methodology Combining Micro-X-Ray Diffraction, Scanning Electron Microscopy-Based Mineral Maps, and Diffuse Reflectance Infrared Fourier Transform Spectroscopy to Characterize Archeological Artifacts. Analytical Chemistry 81: 604-611.

30. J Baeten, K Romanus, P Degryse, WDe Clercq, H Poelman, et al. (2010) Application of a multi-analytical toolset to a $16^{\text {th }}$ century ointment: Identification as lead plaster mixed with beeswax. Microchemical Journal 95: 227-234.

31. E Manzano, A García, E Alarcón, S Cantarero, F Contreras, et al. (2015) An integrated multianalytical approach to the reconstruction of daily activities at the Bronze Age settlement in Peñalosa (Jaén, Spain). Microchemical Journal 122: $127-136$.

32. Theophrastus, De odoribus (1926) Loeb Classical Library (LBC 79). Harvard University Press, Cambridge, USA.

33. Dioscurides, De materia medica (2000) Being an Herbal with many other medicinal materials (I.52-76), translated by Tess Anne Osbaldeston. Ibidis Press, Johannesburg, South Africa.

34. Ovid, Ars amatoria (1929) (Book III) Loeb Classical Library (LBC 232: 12-13). Harvard University Press, Cambridge, USA. 
35. Ovid, De Medicamine Faciei (1929) Loeb Classical Library (LBC 232: 23). Harvard University Press, Cambridge, USA.

36. Plinius Secundus, Historia Naturalis (1938) (Books XIII, XV) Loeb Classical Library (LBC 330: 2-3). Harvard University Press, Cambridge, USA.

37. MC Gamberini, C Baraldi, F Palazzoli, E Ribechini, P Baraldi (2008) MicroRaman and infrared spectroscopic characterization of ancient cosmetics. Vibrational Spectroscopy 47: 82-90.

38. E Ribechini, F Modugno, J Pérez-Arantegui, MP Colombini (2011) Discovering the composition of ancient cosmetics and remedies: analytical techniques and materials. Analytical and Bioanalytical Chemistry 401: 1727-1738.

39. J Pérez Arantegui, G Cepriá, E Ribechini, I Degano, MP Colombini, et al. (2009) Colorants and oils in Roman makeups-an eye witness account. TrAC Trends in Analytical Chemistry 28: 1019-1028.

40. MT Doménech Carbó, ML Vázquez de Agredos Pascual, L Osete Cortina, A Doménech Carbó, N Guasch Ferré, et al. (2012) Characterization of prehispanic cosmetics found in a burial of the ancient city of Teotihuacan (Mexico). Journal of Archaeological Science 39: 1043-1062.

41. R Auriemma (2012) Torre S Sabina: l'approdo ritrovato.

42. R Auriemma, E Solinas (2009) Archaeological remains as sea level change markers: A review. Quaternary International 206: 134-146.

43. A Dell Aglio (2013) Taranto: l'ipogeo delle Gorgoni e le tombe con arco. In: Andreassi G, Cocchiaro A, Dell'Aglio A, Vetustis novitatem dare. Temi di antichità e archeologia in ricordo di Grazia Angela Maruggi, Taranto, 511-530.

44. A Dell Aglio, L Ipogeo delle Gorgoni (2014) Documentazione archeologica. In: Giannotta MT, Gabellone F DellAglio Antonietta A, Fruizione di contesti inacessibili. II progetto Marta Racconta, Lecce, Italy, 178-196.

45. L Grasso (2008) La stipe del santuario di Alaimo a Lentini. Un'area sacra tra la chora e il mare. Monografie dell'Istituto per i Beni Archeologici e Monumentali, 2, Catania.

46. L Grasso (2010) Artemide a Leontini e nelle colonie calcidesi della Sicilia in età arcaica. In: FD Andria, D Malfitana, N Masini, G Scardozzi, II Dialogo dei Saperi. Metodologie integrate per i Beni Culturali, Napoli, 253-266.

47. L. Grasso (2009) The Deity of the Alaimo Sanctuary in Leontinoi (Sicily). BABESCH 84: 17-22.

48. MP Colombini, G Giachi, F Modugno, P Pallecchi, E Ribechini (2003) Characterisation of paints and waterproofing materials of the shipwrecks found in the archaeological site of the Etruscan and Roman harbour of Pisa (Italy). Archaeometry 45: 649-664.

49. E Ribechini, MP Colombini, G Giachi, F Modugno, P Pallecchi (2009) A multi-analytical approach for the characterization of commodities in a ceramic jar from Antinoe (Egypt). Archaeometry 51: 480-494.

50. S Gunasekaran, G Anbalagan, S Pandi (2006) Raman and infrared spectra of carbonates of calcite structure. J Raman Spectrosc 37: 892-899.

51. S Gopi, VK Subramanian, K Palanisamy (2013) Aragonite-calcite-vaterite: A temperature influenced sequential polymorphic transformation of $\mathrm{CaCO} 3$ in the presence of DTPA. Materials Research Bulletin 48: 1906-1912.
52. J Madejovà, P Komadel (2001) Baseline studies of clay minerals society source clays: Infrared methods. Clays and Clay Minerals 49: 410-432.

53. JD Schuttlefield, D Cox, VH Grassian (2007) An investigation of water uptake on clays minerals using ATR-FTIR spectroscopy coupled with quartz crystal microbalance measurements. J Geophys Res 112.

54. B Saikia, G Parthasarathy (2010) Fourier Transform Infrared Spectroscopic characterization of kaolinite from Assam and Meghalaya, Northeastern India. Journal of Modern Physics 1: 206-210.

55. D Seetha, G Velraj (2015) Spectroscopic and statistical approach of archaeological artifacts recently excavated from Tamilnadu, South India. Spectrochimica Acta Part A: Molecular and Biomolecular Spectroscopy 149: 59-68.

56. MP Colombini, G Giachi, M lozzo, E Ribechini (2009) An Etruscan ointment from Chiusi (Tuscany, Italy): its chemical characterization. Journal of Archaeological Science 36: 1488-1495.

57. C Canevali, P Gentile, M Orlandi, F Modugno, JJ Lucejko, et al. (2011) A multi-analytical approach for the characterization of powders from the Pompeii archaeological site. Anal Bioanal Chem 401: 1801-1814.

58. M Maier, DLA de Faria, MT Boschín, SD Parera, MF Castillo Bernal (2007) Combined use of vibrational spectroscopy and GC-MS methods in the characterization of archaeological pastes from Patagonia. Vibrational Spectroscopy 44: 182-186.

59. D Fiore, M Maier, SD Parera, L Orquera, E Piana (2008) Chemical analyses of the earliest pigment residues from the uttermost part of the planet (Beagle Channel region, Tierra del Fuego, Southern South America). Journal of Archaeological Science 35: 3047-3056.

60. MR Derrick, DC Stulik, JM Landry (1999) Infrared Spectroscopy in Conservation Science. The Getty Conservation Institute, Los Angeles.

61. L Brambilla, C Riedo, C Baraldi, A Nevin, MC Gamberini, et al. (2011) Characterization of fresh and aged natural ingredients used in historical ointments by molecular spectroscopic techniques: IR, Raman and fluorescence. Anal Bioanal Chem 401: 1827

62. J Peris Vicente, FM Valle Algarra, MA Ferrer Eres, JV Gimeno Adelantado, L Osete Cortina, et al. (2009) Analytical study of a resinous material used as sealing in ancient pottery found in an archaeological site by thermally assisted hydrolysis methylation-gas chromatography-mass spectrometry, vibrational spectroscopy and light microscopy. Analytical Letters 42: 2637-2647.

63. A Barth (2007) Infrared spectroscopy of proteins. Biochimica et Biophysica Acta - Bioenergetics 1767: 1073-1101.

64. S Dallongeville, N Garnier, C Rolando, C Tokarsk (2016) Proteins in art, archaeology, and paleontology: from detection to identification. Chem Rev 116: 2-79.

65. R Venkatachalapathy, T Sridharan, S Dhanapandian, C Manoharan (2002) Determination of firing temperature of ancient potteries by means of infrared and Mossbauer studies. Spectroscopy Letters 35: 769-779.

66. R Ravisankar, A Naseerutheen, G Raja Annamalai, A Chandrasekaran, A Rajalakshmi, et al. (2014) The analyt- 
ical investigations of ancient pottery from Kaveripakkam, Vellore dist, Tamilnadu by spectroscopic techniques. Spectrochimica Acta A 121: 457-463.

67. S Shoval (2003) Using FT-IR spectroscopy for study of calcareous ancient ceramics. Optical Materials 24: 117-122.

68. F Berna, A Behar, R Shahack Gross, J Berg, E Boaretto, et al. (2007) Sediments exposed to high temperatures: reconstructing pyrotechnological processes in Late Bronze and Iron Age Strata at Tel Dor (Israel). Journal of Archaeological Science 34: 358-373.

69. S Kiruba, S Ganesan (2015) FT-IR and Micro-Raman spectroscopic studies of archaeological potteries recently excavated in Poompuhar, Tamilnadu, India. Spectrochimica Acta A: Molecular and Biomolecular Spectroscopy 145: 594-597.

70. JP Brun (2000) The Production of Perfumes in Antiquity: The Cases of Delos and Paestum. American Journal of Archaeology 104: 277-308.

71. MC Gamberini, C Baraldi, G Freguglia, P Baraldi (2011) Spectral analysis of pharmaceutical formulations prepared according to ancient recipes in comparison with old museum remains. Analytical and Bioanalytical Chemistry 401: 1839-1846.

72. L Zoia, EL Tolppa, L Pirovano, A Salanti, M Oorlandi (2012) ${ }^{1} \mathrm{H}-\mathrm{NMR}$ and ${ }^{31} \mathrm{P}-\mathrm{NMR}$ characterization of the lipid fraction in archaeological ointments. Archaeometry 54: 1076-1099.

73. J Peréz Arantegui, JA Paz Peralta, E Ortiz Palomar (1996) Analysis of products container in two roman glass unguentaria from the colony of Celsa (Spain). Journal of Archaeological Science 23: 649-655.

74. E Welcomme, P Walter, E van Elslande, G Tsoucaris (2006) Investigation of white pigments used as make-up during the Greco-Roman period. Applied Physics A 83: 551-556.

75. PSR Prasad, K Shiva Prasad, V Krishna Chaitanya, EVSSK Babu, B Sreedhar, et al. (2006) In situ FTIR study on the dehydration of natural goethite. Journal of Asian Earth Sciences 27: 503-511.

76. S Prati, G Sciutto, R Mazzeo, C Torri, D Fabbri (2011) Application of ATR-far-infrared spectroscopy to the analysis of natural resins. Analytical and Bioanalytical Chemistry 399: 3081-3091.

77. S Hamm, J Bleton, A Tchapla (2004) Headspace solid phase micro extraction for screening for the presence of resins in Egyptian archaeological samples. Journal of Separation Science 27: 235-243.

78. E Ribechini, F Modugno, MP Colombini, RP Evershed (2008) Gas chromatographic and mass spectrometric investigations of organic residues from Roman glass unguentaria. Journal of Chromatography A 1183: 158-169.

79. A Tchapla, P Méjanelle, J Bleton, S Goursaud (2004) Characterisation of embalming materials of a mummy of the Ptolemaic era. Comparison with balms from mummies of different eras. Journal of Separation Science 27: 217-234.

80. SA Buckley, RP Evershed (2001) Organic chemistry of embalming agents in Pharaonic and Graeco-Roman mummies. Nature 413: 837-841.

81. F Notarstefano, M Lettieri, G Semeraro, L Troisi (2011) Food habits and social identity during Archaic age: chemical analyses of organic residues on pottery vessels from the Messapian settlement of San Vito dei Normanni (South-Eastern Italy). In: I Turbanti Memmi, Proceeding $37^{\text {th }}$ International Symposium on Archaeometry, $13^{\text {th }}-16^{\text {th }}$ May 2008, Siena, Berlin, Italy, 465-471.

82. RP Evershed (1996) Proteinaceous Material from Potsherds and Associated Soils. Journal of Archaeological Science 23: 429-436.

83. H Mai, Y Yang, I Abuduresule, W Li, X Hu, et al. (2016) Characterization of cosmetic sticks at Xiaohe Cemetery in early Bronze Age Xinjiang, China. Scientific Reports 6.

84. J Madejová (2003) FTIR techniques in clay mineral studies. Vibrational Spectroscopy 31: 1-10.

85. A Lòpez Galindo, C Viseras (2004) Pharmaceutical and cosmetic applications of clays. In: F Wypych, KG Satyanarayana, Clay Surfaces - Fundamentals and Applications. Interface Science and Technology 1: 267-289.

86. MI Carretero, M Pozo (2010) Clay and non-clay minerals in the pharmaceutical and cosmetic industries Part II. Active ingredients. Applied Clay Science 47: 171-181. 